\title{
Self-Management for Men With Lower Urinary Tract Symptoms: A Systematic Review and Meta-Analysis
}

\author{
Loai Albarqouni, MD, MSc, $P b D^{1}$ \\ Sharon Sanders, $P b D^{1}$ \\ Justin Clark, BA ${ }^{1}$ \\ Kari A. O. Tikkinen, $M D, P b D^{2,3}$ \\ Paul Glasziou, MBBS, $P b D^{1}$ \\ 'Institute for Evidence-Based Healthcare, \\ Faculty of Health Sciences and Medicine, \\ Bond University, Queensland, Australia \\ ${ }^{2}$ Department of Urology, University \\ of Helsinki and Helsinki University \\ Hospital, Helsinki, Finland \\ ${ }^{3}$ Department of Surgery, South Karelian \\ Central Hospital, Lapeenranta, Finland
}

Conflicts of interest: authors report none.

\author{
CORRESPONDING AUTHOR \\ Loai Albarqouni \\ Institute for Evidence-Based Healthcare \\ Faculty of Health Sciences and Medicine \\ Bond University \\ 14 University Dr, Robina \\ QLD, Australia 4229 \\ lalbarqo@bond.edu.au
}

\begin{abstract}
PURPOSE Lower urinary tract symptoms are very common in older men. We conducted a systematic review and meta-analysis to evaluate the effects of selfmanagement interventions on these symptoms.

METHODS We included randomized controlled trials comparing the effect of self-management interventions (alone or combined with drug therapy) with usual care or drug therapy alone in men with lower urinary tract symptoms. Two independent reviewers screened retrieved articles, extracted data, and assessed the risk of bias of included studies. The primary outcome was lower urinary tract symptom severity. Where data were available, we calculated mean differences (MDs) between the interventions.
\end{abstract}

RESULTS Analyses were based on 8 studies among 1,006 adult men. Seven of these studies were judged to be at high risk in 2 of the 7 domains of bias. The nature of the self-management interventions varied across studies. There was a clinically important reduction in the 35-point International Prostate Symptom Score at 6 months favoring self-management interventions compared with usual care ( $\mathrm{MD}=-7.4 ; 95 \% \mathrm{Cl},-8.8$ to $-6.1 ; 2$ studies). The reduction in score with self-management was similar to that achieved with drug therapy at 6 to 12 weeks ( $M D=0.0 ; 95 \% \mathrm{Cl}_{1}-2.0$ to $2.0 ; 3$ studies). Self-management had a smaller, additional benefit at 6 weeks when added to drug therapy $(\mathrm{MD}=-2.3$; $95 \% \mathrm{Cl}_{1}-4.1$ to -0.5 ; 1 study).

CONCLUSIONS We found moderate-quality evidence (suggesting reasonable certainty in estimates) for the effectiveness of self-management for treating lower urinary tract symptoms in men. We therefore recommend the use of self-management interventions for this patient population.

Ann Fam Med 2021;19:157-167. https://doi.org/10.1370/afm.2609.

\section{INTRODUCTION}

L ower urinary tract symptoms are a common problem among older men, ${ }^{1}$ affecting $70 \%$ to $90 \%$ of those aged 80 years and older. ${ }^{2,3}$ These symptoms can be divided into storage symptoms (eg, increased urinary frequency, urgency, nocturia, incontinence), voiding symptoms (eg, hesitancy, poor stream, incomplete emptying, dribbling), and postmicturition symptoms. ${ }^{4}$ Male lower urinary tract symptoms have traditionally been related to bladder outlet obstruction, which is often caused by prostatic enlargement resulting from benign prostatic hyperplasia $(\mathrm{BPH})$. An increasing number of studies have shown, however, that these symptoms are often unrelated to the prostate. ${ }^{5,6}$ Indeed, they can be caused by various conditions within or outside the lower urinary tract, including detrusor overactivity or underactivity, and urethral diseases. ${ }^{7}$ Although voiding symptoms are the most common, they are generally less bothersome than storage symptoms, which are the most typical reason men seek medical care. ${ }^{8,9}$ Lower urinary tract symptoms can have a substantial negative impact on quality of life, ${ }_{1}^{10}$ including impaired social functioning ${ }^{11}$ and sleep disturbance from nocturia. ${ }^{12}$

Self-management interventions are "structured interventions aimed at improving individual's medical, behavioral, and emotional condition in 
order to give individuals some control over their symptoms. ${ }^{13-15}$ Brown et $\mathrm{al}_{1}{ }^{16}$ through a formal consensus process, defined main components of self-management interventions for lower urinary tract symptoms in men. Most cases can be effectively managed in primary care with a stepwise management approach (ie, usual care), beginning with watchful waiting and progressing to drug and surgical interventions if necessary. ${ }^{6}$ Although several guidelines for managing lower urinary tract symptoms in men recommend self-management as one of several treatment options such as watchful waiting, ${ }^{6,8}$ self-management interventions are rarely considered a definitive treatment option. These interventions only occasionally appear in patient decision aids. For instance, the widely used and respected Ottawa Hospital Research Institute catalog of patient decision aids (https://decisionaid.ohri.ca) lists 3 patient decision aids for treating lower urinary tract symptoms, but none of these appear to consider self-management interventions.

We are unaware of any previous systematic reviews synthesizing the evidence for the effect of self-management interventions in men with lower urinary tract symptoms. Existing reviews have evaluated the effect of self-management interventions on specific symptoms only (eg, urinary incontinence), focused on general lifestyle interventions such as physical activity, and included both men and women. ${ }^{17-20}$ Recently, a scoping review was conducted to inform the development of an online personalized self-management intervention for men with lower urinary tract symptoms, and it identified few studies of self-management interventions; moreover, no quantification or pooling of their effects was conducted. ${ }^{21}$ We therefore undertook a systematic review of randomized controlled trials (RCTs) that have compared self-management interventions with either control/usual care or drug therapy for reducing lower urinary tract symptoms among adult men.

\section{METHODS}

This systematic review is reported following the Preferred Reporting Items for Systematic Reviews and Meta-Analyses (PRISMA) statement. ${ }^{22}$ The review protocol was prospectively developed and registered on the Open Science Framework (https://osf.io/whkqz).

\section{Eligibility Criteria}

\section{Participants}

We included RCTs among men experiencing lower urinary tract symptoms whether storage symptoms, voiding symptoms, or both. When eligible studies included both sexes, we used the data for men only. We excluded studies that involved men who had lower urinary tract symptoms attributed to infections (eg, urinary tract infection or prostatitis), men who had prostate cancer or had undergone prostate surgery, and men with concomitant neurologic conditions (eg, stroke or Parkinson disease).

\section{Interventions and Comparators}

The main components of self-management interventions for men with lower urinary tract symptoms have been identified using a formal consensus process: (1) education and reassurance, (2) fluid management, (3) reduction of caffeine and alcohol intake, (4) use of concurrent medication, (5) toilet and bladder training, and (6) miscellaneous interventions. ${ }^{16,23}$ We included trials evaluating either one or some combination of these components of self-management, with or without concomitant drug therapy. For this review, we defined a self-management intervention as one involving at least 2 of the above components. We excluded studies that compared only drug interventions. We also excluded studies that evaluated general lifestyle interventions (eg, physical activity and weight loss) as these interventions have been previously evaluated in systematic reviews, ${ }_{1}^{17,18}$ have not been identified by Brown et $\mathrm{a}^{16}$ as one of the main components of self-management intervention, and do not give patients control over specific symptoms.

We included studies comparing self-management interventions with control (ie, usual care) or drug therapy. There is no universal agreement on what constitutes usual care; therefore, we accepted the authors' definition of usual care, which frequently included watchful waiting.

\section{Outcomes}

The primary outcome was lower urinary tract symptom severity measured using validated symptom scores, for example, the International Prostate Symptom Score (IPSS) and the American Urological Association Symptom Index (AUA-SI). We also included studies reporting on other outcomes relevant to patients, such as quality of life and symptom frequency (eg, 24-hour voiding frequency or nocturia).

\section{Study Identification and Selection}

One of the authors, a senior information specialist (J.C.), conducted a search of PubMed, EMBASE, and the Cochrane Central Register of Controlled Trials (CENTRAL) from inception to July 10, 2019 for published RCTs, using the search strategy described in Supplemental materials, available at https://www.AnnFamMed. org/content/19/2/157/suppl/DC1/. We used a combination of search words and subject terms (MeSH terms). No language or date restrictions were applied. The database searches were supplemented with a backward and forward citation search of included studies using the 
Scopus database (conducted on July 17, 2019). We also searched ClinicalTrials.gov and the World Health Organization's International Clinical Trials Registry Platform for registered ongoing or unpublished studies and for additional data from published studies.

Two authors (L.A., S.S.) independently screened titles and abstracts and full-text articles against the eligibility criteria. Any disagreements were resolved through discussion and consultation with a third author (P.G.) if necessary.

\section{Data Extraction and Quality Assessment}

Two authors (L.A., S.S.) independently extracted data into a prespecified, pilot-tested form. We extracted data on study characteristics, participants, interventions, comparators, and outcomes. We requested data from authors of trials who had obtained but not presented usable outcome data (ie, provided data combined for men and women combined, but not for men only). Two authors (L.A., S.S.) independently assessed the risk of bias of each included study using the Cochrane Collaboration's tool for assessing risk of bias in randomized trials. ${ }^{24}$ Any disagreements were resolved through discussion and consultation with a third author (P.G.) if necessary.

\section{Data Analysis}

We specified the following 4 comparisons: (1) self-management vs usual care ${ }_{i}(2)$ self-management vs drug therapy ${ }_{i}(3)$ combined self-management and drug therapy vs drug therapy alone; and (4) a single component of selfmanagement vs another single component.

We performed meta-analyses only when we considered studies to be sufficiently clinically and methodologically homogeneous, and when at least 2 studies reported comparable data measuring the same outcomes. We used mean differences (MDs) to measure intervention effects of continuous outcomes. Where studies used different scales to measure the same outcome, we used standardized mean differences. We reported all effect measures with 95\% confidence intervals. We used Review Manager 5 (The Cochrane Collaboration) to analyze data.

\section{Assessment of Heterogeneity and Reporting Biases}

We considered both clinical and statistical heterogeneity. We evaluated statistical heterogeneity using the $\chi^{2}$ test $(P<.10$ was considered statistically significant heterogeneity) and the $\mathrm{I}^{2}$ statistic $\left(\mathrm{I}^{2}>60 \%\right.$ was considered substantial heterogeneity $\left.{ }^{25}\right)$.

\section{RESULTS}

We screened 2,872 titles and abstracts, and obtained full text for 99 records (Figure 1). We excluded 67 full-text articles, including 21 studies (pertaining to 32

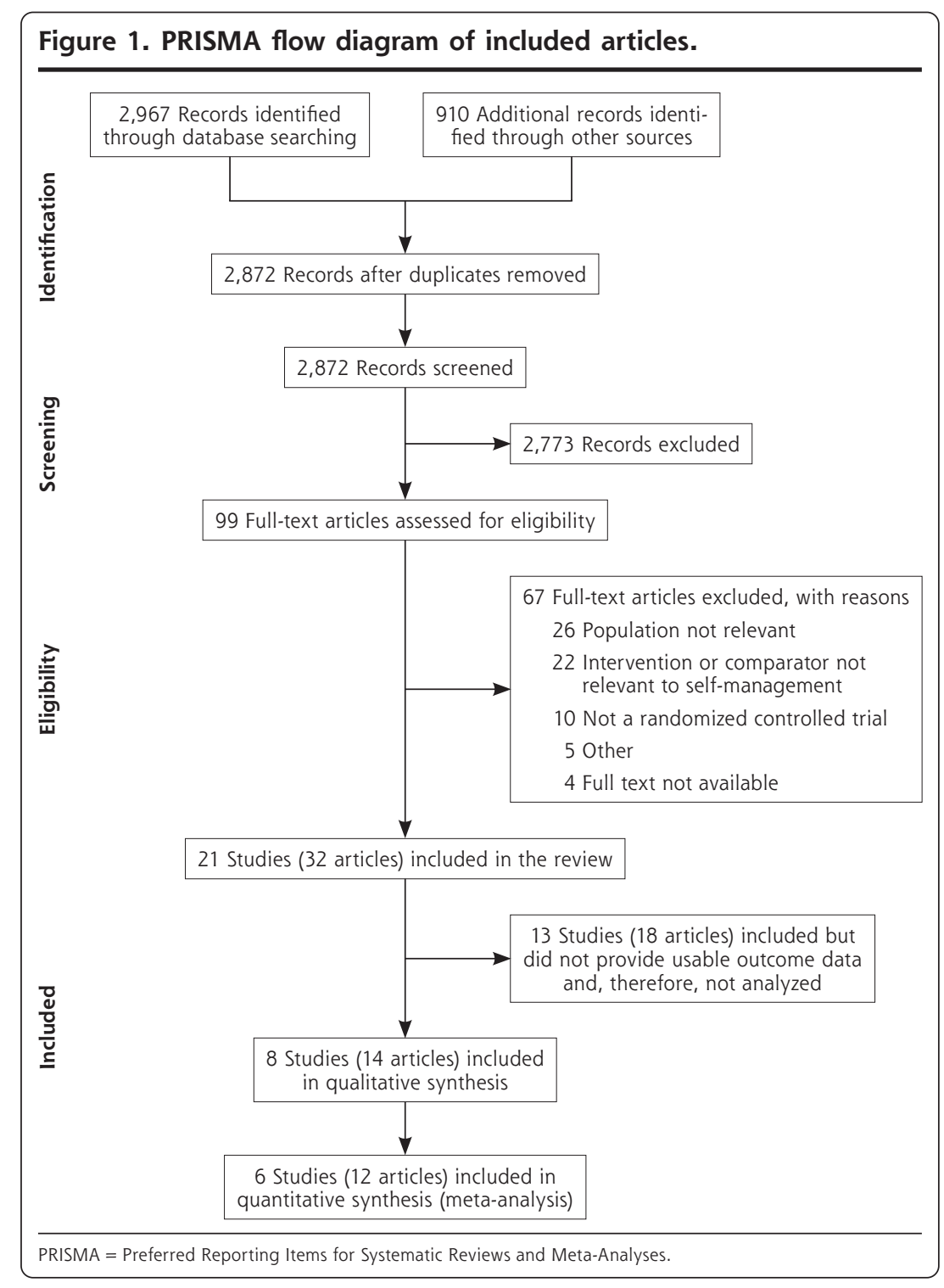


Table 1. Characteristics of Included Studies $(\mathrm{N}=8)$

\begin{tabular}{|c|c|c|c|}
\hline $\begin{array}{l}\text { Study Author, } \\
\text { Year (Location) }\end{array}$ & $\begin{array}{l}\text { Condition/Symptoms; } \\
\text { Setting; Age }\end{array}$ & Groups $^{b}$ & Cointerventions \\
\hline $\begin{array}{l}\text { Brown et al, }{ }^{23,36,42} 2007 \\
\text { (UK) }\end{array}$ & $\begin{array}{l}\text { LUTS; outpatient clinic; group 1: } 63 \\
\text { years, group 2: } 63 \text { years }\end{array}$ & Self-management vs usual care & $\begin{array}{l}\text { Escalation of medication or } \\
\text { surgery at discretion of } \\
\text { patient and clinician }\end{array}$ \\
\hline $\begin{array}{l}\text { Chen et al, }{ }^{26} 2012 \\
\text { (China) }\end{array}$ & $\begin{array}{l}\text { LUTS with BPH; outpatient clinic; group } \\
\text { 1: } 71 \text { years, group 2: } 69 \text { years }\end{array}$ & Self-management vs usual care & BPH education \\
\hline $\begin{array}{l}\text { Burgio et al (MOTIVE } \\
\text { trial), }{ }^{29,43,44} 2011 \text { (USA) }\end{array}$ & $\begin{array}{l}\text { OAB: urgency and frequency } \pm \text { urge } \\
\text { incontinence; community and Veter- } \\
\text { ans Affairs Medical Centers; group 1: } \\
63 \text { years, group 2: } 64 \text { years }\end{array}$ & $\begin{array}{l}\text { Behavioral treatment vs antimuscarinic } \\
\text { (oxybutynin } 5 \text { to } 39 \text { mg daily individually } \\
\text { titrated) }\end{array}$ & $\begin{array}{l}\text { Fluid management hand- } \\
\text { out, bladder diary, and } \\
\alpha \text {-blocker }\end{array}$ \\
\hline $\begin{array}{l}\text { Johnson et al (BEDTiMe } \\
\text { trial), }{ }^{31,45} 2016 \text { (USA) }\end{array}$ & $\begin{array}{l}\text { Nocturia; primary care clinics; group 1: } \\
66 \text { years, group 2: } 63 \text { years, group } \\
\text { 3: } 67 \text { years }\end{array}$ & $\begin{array}{l}\text { Behavioral treatment and exercise therapy } \\
\text { vs } \alpha \text {-blocker (tamsulosin } 0.4 \text { mg nightly) } \\
\text { vs behavioral treatment and exer- } \\
\text { cise }+\alpha \text {-blocker (tamsulosin } 0.4 \text { mg nightly) }\end{array}$ & $\begin{array}{l}\text { Antimuscarinic, } 5 \text { - } \alpha \text { reduc- } \\
\text { tase inhibitor, sedative- } \\
\text { hypnotic as needed }\end{array}$ \\
\hline $\begin{array}{l}\text { Hut et al, }{ }^{27} 2017 \\
\text { (Netherlands) }\end{array}$ & $\begin{array}{l}\text { LUTS: moderate to severe; primary care } \\
\text { clinics; } 51-82 \text { years }\end{array}$ & $\begin{array}{l}\text { Pelvic floor muscle therapy + behavioral treat- } \\
\text { ment vs } \alpha \text {-blocker (tamsulosin } 0.4 \text { mg daily) }\end{array}$ & None \\
\hline $\begin{array}{l}\text { Burgio et al (COBALT } \\
\text { trial), }{ }^{30,46,47} 2018 \text { (USA) }\end{array}$ & $\begin{array}{l}\text { OAB: urgency and frequency; commu- } \\
\text { nity; group 1: } 63 \text { years, group 2: } 65 \\
\text { years, group 3: } 63 \text { years }\end{array}$ & $\begin{array}{l}\text { Behavioral treatment vs antimusca- } \\
\text { rinic }+\alpha \text {-blocker (tolterodine } 4 \mathrm{mg}+\text { tam- } \\
\text { sulosin } 0.4 \text { mg daily) vs behavioral treat- } \\
\text { ment }+ \text { antimuscarinic }+\alpha \text {-blocker (toltero- } \\
\text { dine } 4 \mathrm{mg}+\text { tamsulosin } 0.4 \text { mg daily) }\end{array}$ & None \\
\hline $\begin{array}{l}\text { Paterson et al, }{ }^{32} 1997 \\
\quad \text { (Australia) }\end{array}$ & $\begin{array}{l}\text { Postmicturition dribble; outpatient } \\
\text { clinic; } 36-83 \text { years }\end{array}$ & $\begin{array}{l}\text { Counseling vs pelvic muscle exercises vs ure- } \\
\text { thral milking }\end{array}$ & None \\
\hline $\begin{array}{l}\text { Spigt et al, }{ }^{28} 2006 \\
\text { (Netherlands) }\end{array}$ & $\begin{array}{l}\text { LUTS: moderate; general practice clin- } \\
\text { ics; } 55-75 \text { years }\end{array}$ & Increased water consumption vs placebo & None \\
\hline \multicolumn{4}{|c|}{$\begin{array}{l}\text { AUA-QoL = American Urological Association Quality of Life score; AUA-SI = American Urological Association Symptom Index; BEDTiMe = Behavior and Exercise Ver- } \\
\text { sus Drug Treatment in Men With Nocturia; BPH = benign prostatic hyperplasia; COBALT = Combined Behavioral and Drug Treatment of Overactive Bladder in Men; } \\
\text { IPSS = International Prostate Symptom Score; LUTS = lower urinary tract symptoms; MOTIVE = Male Overactive Bladder Treatment in Veterans; OAB = overactive bladder. }\end{array}$} \\
\hline \multicolumn{4}{|c|}{$\begin{array}{l}\text { a Mean or range. Groups are described in next column. } \\
\text { b As described by study authors. Intervention content varies despite similar titles. } \\
\text { ' Group } 1 / \text { group } 2 / \text { group } 3 \text {. } \\
\text { d From randomization unless otherwise indicated. } \\
\text { e Unclear whether time from randomization, start of intervention, or end of intervention. } \\
{ }^{f} \text { Only the number analyzed was available ( } 43 \text { of } 49 \text { randomized). }\end{array}$} \\
\hline
\end{tabular}

articles) in the review. We were able to extract outcome data from 8 studies (14 articles) and included 6 studies (12 articles) in meta-analysis. Details of the remaining 13 studies (18 articles) that did not provide usable outcome data (ie, provided data combined for men and women combined, but not for men only) are given in Supplemental Table 1, available at https://www.AnnFam Med.org/content/19/2/157/supp1/DC1/. Excluded fulltext articles are listed in Supplemental Table 2, available at https://www.AnnFamMed.org/content/19/2/157/ suppl/DC1/, with the reason for exclusion.

\section{Characteristics of Included Studies}

The included studies enrolled a total of 1,006 men with a median of 141 men per trial and a range of 41 to 222 (Table 1). Of the 8 included studies, 4 recruited men with a range of lower urinary tract symptoms ${ }_{,}^{23,26-28} 2$ included men with storage symptoms only, ${ }^{29,30}$ and 2 included men with a single lower urinary tract symptom (nocturia ${ }^{31}$ or postmicturition dribble ${ }^{32}$ ). Most of the participants in the included studies had moderate symptoms (range of mean IPSS scores at baseline $=12$ to 20). All studies recruited men from primary care or community settings. Three studies had a follow-up duration of 6 months or longer, with a median for all studies of 3 months (range $=6$ weeks to 12 months).

Of the 8 included studies, 2 studies compared selfmanagement with usual care, which was referred to as the control in these studies (Table 1) ${ }^{23,26,33}$ Four studies compared self-management with drug therapy, ${ }_{1}^{27,29-31}$ with 2 of them also evaluating the combination of self-management and drug therapy. ${ }^{30,31}$ Two studies compared single components of self-management: 


\begin{tabular}{|c|c|c|}
\hline $\begin{array}{l}\text { No. } \\
\text { Randomizedc }\end{array}$ & $\begin{array}{l}\text { Outcomes Assessed } \\
\text { Here (Outcome } \\
\text { Assessment Tool) }\end{array}$ & $\begin{array}{l}\text { Time of } \\
\text { Outcome } \\
\text { Assessment }\end{array}$ \\
\hline $73 / 67$ & $\begin{array}{l}\text { Symptom severity (IPSS); qual- } \\
\text { ity of life (AUA-QoL score); } \\
\text { nocturia episodes; } 24 \text {-hour } \\
\text { voiding frequency }\end{array}$ & $3,6,12$ months $^{\mathrm{e}}$ \\
\hline $119 / 103$ & $\begin{array}{l}\text { Symptom severity (IPSS); qual- } \\
\text { ity of life (BPH-QoL score) }\end{array}$ & $\begin{array}{l}1 \text { week, } \\
3 \text { months, } \\
6 \text { months }\end{array}$ \\
\hline $73 / 70$ & $\begin{array}{l}\text { Symptom severity (AUA-SI); } \\
\text { 24-hour voiding frequency } \\
\text { (7-day bladder diary); noc- } \\
\text { turia episodes }\end{array}$ & 8 weeks \\
\hline $23 / 25 / 24$ & $\begin{array}{l}\text { Nocturia episodes (AUA-SI } \\
\text { nocturia question) }\end{array}$ & $\begin{array}{l}2,4,10,12 \\
\text { weeks }\end{array}$ \\
\hline $22 / 19$ & Symptom severity (IPSS) & 3 months \\
\hline $71 / 68 / 65$ & $\begin{array}{l}\text { Symptom severity (AUA-SI); } \\
\text { 24-hour voiding frequency } \\
\text { (7-day bladder diary); } \\
\text { nocturia episodes (AUA-SI } \\
\text { nocturia question) }\end{array}$ & 6 weeks \\
\hline $15 / 15 / 13^{f}$ & $\begin{array}{l}\text { Urine loss (weight of inconti- } \\
\text { nence pad) }\end{array}$ & $5,9,13$ weeks \\
\hline $70 / 71$ & Symptom severity (IPSS) & 6 months \\
\hline
\end{tabular}

increased water consumption vs placebo ${ }^{28}$ and urethral milking vs pelvic floor exercises vs counseling. ${ }^{32}$ Self-management interventions varied among included studies, with 2 studies including all of the components of self-management identified by Brown et al. ${ }^{16}$ Fluid management and toileting components were included in self-management in 6 of the studies. Details on the components comprising the self-management interventions are shown in Table 2. We also found considerable variation between studies in the delivery of self-management interventions to participants (eg, delivered in groups vs individually and delivered at multiple time points vs once).

\section{Risk of Bias Assessment}

Of the 8 included studies, 7 were judged to be at high risk in more than 1 domain of bias (Figure 2). All studies were judged to be at high or unclear risk of bias for concealment of allocation. All except a single study were judged to be at high risk of performance bias; this study was considered low risk because participants in the self-management group received placebo pills and participants in the drug therapy group received extended clinical visits. ${ }^{31}$ One-half of the studies (4 of 8) were judged to be at unclear risk of bias from selective reporting.

\section{Effects of the Intervention}

Six of the 8 included studies reported data on outcomes of interest that could be synthesized. We describe the outcomes, according to the comparisons of interest, below.

\section{Self-Management vs Usual Care}

Two included studies compared self-management with usual care among a total of 350 participants that reported data on symptom severity assessed with the IPSS, ${ }^{23,26}$ a 35 -point scale on which a reduction of more than 3 points is considered clinically meaningful. ${ }^{34,35}$ The self-management intervention significantly reduced symptom severity at 6 months compared with usual care $(\mathrm{MD}=-7.44 ; 95 \% \mathrm{CI},-8.82$ to -6.06 ; $\left.\mathrm{I}^{2}=14 \%\right)$ (Figure $\left.3 \mathrm{~A}\right)$.

In terms of secondary outcomes, compared with peers given usual care, men in the self-management group reported fewer episodes of nocturia $(\mathrm{MD}=-0.60$; $95 \% \mathrm{CI},-1.12$ to $-0.08 ; 1$ study $^{36}$; Supplemental Figure 2A, available at https://www.AnnFamMed.org/ content/19/2/157/suppl/DC1/) and voiding in 24 hours $\left(\mathrm{MD}=-1.60 ; 95 \% \mathrm{CI},-2.90\right.$ to $-0.30 ; 1$ study $^{36}$; Supplemental Figure 1A, available at https://www. AnnFamMed. org/content/19/2/157/suppl/DC1/) at 12 months.

Men in the self-management groups reported better quality of life relative to counterparts in the usual care group at 6 months in both studies. In the study by Brown et al ${ }_{1}{ }^{23}$ outcome was assessed with a 13-point $\mathrm{BPH}$ impact index on which a reduction of greater than 0.4 points is considered clinically meaningful ${ }^{34}$ $(\mathrm{MD}=-1.4 ; 95 \% \mathrm{CI},-2.4$ to -0.4$)$. The study by Chen et $\mathrm{al}^{26}$ used a 90 -point $\mathrm{BPH}$ quality of life score $(\mathrm{MD}=-20.4 ; 95 \% \mathrm{CI},-24.15$ to -16.65$)$. Results are detailed in Supplemental Figure 3 (https://www.Ann FamMed.org/content/19/2/157/suppl/DC1/).

Treatment failure (a rise of more than 3 points on the IPSS, initiation of drug therapy to control symptoms, acute urinary retention, or surgical intervention) was more frequent with usual care compared with selfmanagement at 6 and 12 months (absolute risk difference at 12 months $=48 \%$; $95 \% \mathrm{CI}, 32 \%$ to $64 \%) .{ }^{23}$

Neither of the 2 studies reported any adverse events related to the interventions. 
Table 2. Details of the Self-Management Interventions Evaluated in Included Studies $(\mathbf{N}=8)$

\begin{tabular}{|c|c|c|c|c|}
\hline \multirow[b]{2}{*}{$\begin{array}{l}\text { Study Author, } \\
\text { Year }\end{array}$} & \multicolumn{4}{|c|}{ Component } \\
\hline & $\begin{array}{l}\text { Education and } \\
\text { Reassurance }^{a}\end{array}$ & Fluid Management & $\begin{array}{l}\text { Caffeine and Alcohol } \\
\text { Reduction }\end{array}$ & $\begin{array}{l}\text { Concurrent } \\
\text { Medication }\end{array}$ \\
\hline Brown et al, 23,36,42 2007 & $\begin{array}{l}\text { Causes and natural } \\
\text { history of symptoms; } \\
\text { reassurance about } \\
\text { prostate cancer }\end{array}$ & $\begin{array}{l}\text { Timing (restriction before } \\
\text { bedtime/social activities); } \\
\text { amount }(1.5-2 \mathrm{~L})\end{array}$ & $\begin{array}{l}\text { Caffeine (replace with decaf); } \\
\text { alcohol (avoid in evening; } \\
\text { reduce intake) }\end{array}$ & $\begin{array}{l}\text { Reschedule and/or sub- } \\
\text { stitute (diuretics) }\end{array}$ \\
\hline Chen et al, ${ }^{26} 2012$ & $\begin{array}{l}\text { Causes of symptoms; } \\
\text { reassurance about } \\
\text { prostate cancer }\end{array}$ & $\begin{array}{l}\text { Timing (restriction before } \\
\text { social activities/evening); } \\
\text { amount (not excessive) }\end{array}$ & $\begin{array}{l}\text { Caffeine (avoid); alcohol } \\
\text { (avoid) }\end{array}$ & Reschedule (diuretics) \\
\hline $\begin{array}{l}\text { Burgio et al, }{ }^{29,43,44} 2011 \\
\text { (MOTIVE trial) }\end{array}$ & NR & Timing (restriction after 6 PM) & NR & $N R$ \\
\hline $\begin{array}{l}\text { Johnson et al, }{ }^{31,45} 2016 \\
\text { (BEDTime trial) }\end{array}$ & NR & $\begin{array}{l}\text { Timing (restriction before } \\
\text { bedtime); amount (1.5-2 L) }\end{array}$ & $\begin{array}{l}\text { Caffeine (avoid); alcohol } \\
\text { (reduce before bedtime) }\end{array}$ & NR \\
\hline
\end{tabular}

\begin{tabular}{lll}
\hline Hut et al, $272017 \quad$ Amount $(\geq 2 \mathrm{~L}) \quad$ Caffeine (limit); alcohol (limit) \\
$\begin{array}{l}\text { and relationship } \\
\text { with symptoms }\end{array}$
\end{tabular}

\begin{tabular}{|c|c|c|c|c|}
\hline $\begin{array}{l}\text { Burgio et al, } 30,46,47 \\
2018 \text { (COBALT trial) }\end{array}$ & NR & $\begin{array}{l}\text { Timing (restriction before } \\
\text { bedtime and at night) }\end{array}$ & NR & NR \\
\hline \multirow[t]{3}{*}{ Paterson et al, ${ }^{32} 1997^{c}$} & NR & NR & NR & NR \\
\hline & NR & NR & NR & NR \\
\hline & NR & Timing & Advice on types of beverages & NR \\
\hline Spigt et al, ${ }^{28} 2006$ & $N R$ & $\begin{array}{l}\text { Amount (1.5 L of extra water } \\
\text { daily) }\end{array}$ & NR & NR \\
\hline
\end{tabular}

BEDTiMe = Behavior and Exercise Versus Drug Treatment in Men With Nocturia; BPH = benign prostatic hyperplasia; COBALT = Combined Behavioral and Drug Treatment of Overactive Bladder in Men; LUTS = lower urinary tract symptoms; MOTIVE = Male Overactive Bladder Treatment in Veterans; NR = not reported.

aAimed at increasing participants' knowledge of the causes and natural history of BPH and LUTS.

b Nurses asked, "Overall, how completely do you think you followed your treatment instructions?" On scale of 1 to 5 points, 4 corresponded to "most of the time."

"Study evaluated 3 single components of self-management for treating lower urinary tract symptoms: pelvic floor exercises (first row) vs urethral milking (second row) vs counseling (third row).

\section{Self-Management vs Drug Therapy}

Four of the included studies compared self-management with drug therapy. ${ }^{27,29,30,31}$ Three of these studies, with a total of 302 participants, reported data on symptom severity assessed using the IPSS or the AUA-SI. ${ }^{27,29,30}$ We found no evidence of a difference in symptom severity between self-management and drug therapy at 6 to 12 weeks $(\mathrm{MD}=0.00 ; 95 \% \mathrm{CI},-1.95$ to $1.96 ; \mathrm{I}^{2}=57 \%$ ) (Figure 3B).

In terms of secondary outcomes, we found a difference in nocturia episodes favoring selfmanagement $(\mathrm{MD}=-0.42 ; 95 \% \mathrm{CI},-0.67$ to -0.17 ; 3 studies $^{29-31} ; \mathrm{I}^{2}=0 \%$; Supplemental Figure 2B, https://www. AnnFamMed.org/content/19/2/157/ suppl/DC1/) at 6 to 12 weeks, but no evidence of a difference in 24-hour voiding frequency $\left(\mathrm{MD}=-0.96 ; 95 \% \mathrm{CI},-2.04\right.$ to $0.12 ; 2$ studies $^{29,30}$; $\mathrm{I}^{2}=70 \%$; Supplemental Figure 1A, https://www. Ann FamMed.org/content/19/2/157/suppl/DC1/) at 6 to 8 weeks.

One study reported 1 serious adverse event among 71 participants $(1.41 \%)$ in the self-management group, compared with 2 in 68 participants $(2.94 \%)$ in the drug therapy group. ${ }^{30}$

Two studies reported data on patients' perception of bothersome side effects (rated on a scale with 5 response options, ranging from "no side effects" to "extremely bothersome"). ${ }^{29,30}$ Participants in the drug therapy group reported side effects $26 \%$ more frequently than peers in the self-management group 


\section{Component}

Toileting and Bladder Retraining

Types of toileting (double voiding, urethral milking); bladder retraining (pelvic floor exercise, urge suppression, bladder diaries)

\begin{tabular}{|c|c|c|c|}
\hline $\begin{array}{l}\text { Miscellaneous } \\
\text { (Advice) }\end{array}$ & $\begin{array}{l}\text { Delivery Format I } \\
\text { Clinician }\end{array}$ & $\begin{array}{l}\text { Duration/ } \\
\text { Dose }\end{array}$ & Fidelity: Planned/Actual \\
\hline $\begin{array}{l}\text { Avoiding } \\
\text { constipation }\end{array}$ & $\begin{array}{l}\text { Group sessions/ } \\
\text { trained specialist } \\
\text { nurses }\end{array}$ & $\begin{array}{l}3 \text { sessions, } \\
1.5-2 \text { hours } \\
\text { each }\end{array}$ & $\begin{array}{l}\text { Specialist nurses trained in group facil- } \\
\text { itation and techniques to enhance } \\
\text { self-management skills/93\% of par- } \\
\text { ticipants attended all sessions }\end{array}$ \\
\hline $\begin{array}{l}\text { Avoiding constipa- } \\
\text { tion; drinking } \\
\text { cranberry juice }\end{array}$ & $\begin{array}{l}\text { Individual face-to- } \\
\text { face and telephone } \\
\text { follow-up/NR }\end{array}$ & $\begin{array}{l}1 \text { session, } \\
2 \text { hours }\end{array}$ & NR/NR \\
\hline NR & $\begin{array}{l}\text { NR/nurse } \\
\text { practitioners }\end{array}$ & $\begin{array}{l}4 \text { sessions } \\
\text { over } 8 \\
\text { weeks }\end{array}$ & $\begin{array}{l}\text { NR/88\% of participants attended all } \\
\text { sessions }\end{array}$ \\
\hline $\begin{array}{l}\text { Sleep hygiene; } \\
\text { peripheral edema } \\
\text { management }\end{array}$ & $\begin{array}{l}\text { Individual face-to- } \\
\text { face or telephone/ } \\
\text { nurse practitioners }\end{array}$ & $\begin{array}{l}4 \text { sessions } \\
\text { over } 10 \\
\text { weeks }\end{array}$ & $\begin{array}{l}\text { Specialist nurses trained on how to } \\
\text { administer behavioral treatments } \\
\text { (3-hour initial session and twice- } \\
\text { monthly research meetings)/median } \\
\text { score }=4 \text { on } 5 \text {-point scale }{ }^{b}\end{array}$ \\
\hline $\begin{array}{l}\text { Avoiding } \\
\text { constipation }\end{array}$ & $\begin{array}{l}\text { Individual sessions/ } \\
\text { NR }\end{array}$ & $\begin{array}{l}6 \text { sessions, } \\
0.5-1 \text { hour } \\
\text { each, over } \\
90 \text { days }\end{array}$ & NR/NR \\
\hline NR & NR/NR & $\begin{array}{l}3 \text { sessions } \\
\text { over } 6 \\
\text { weeks }\end{array}$ & NR/NR \\
\hline $\begin{array}{l}\text { NR } \\
\text { NR }\end{array}$ & $\begin{array}{l}\text { NR/study chief } \\
\text { investigator }\end{array}$ & NR/NR & $\begin{array}{l}\text { NR/99\% completed required clinic } \\
\text { visits }\end{array}$ \\
\hline \multicolumn{4}{|l|}{$\begin{array}{l}\text { Edema manage- } \\
\text { ment; diet }\end{array}$} \\
\hline NR & $\begin{array}{l}\text { NR/person not } \\
\text { involved in effect } \\
\text { measurements }\end{array}$ & & $\begin{array}{l}\text { Participants provided with } 0.5-\mathrm{L} \\
\text { glasses/24-hour water turnover } \\
\text { increased by } 359 \text {-ml in intervention } \\
\text { group compared with placebo group }\end{array}$ \\
\hline
\end{tabular}

Types of toileting (double voiding, prompt voiding, urethral milking); bladder retraining (pelvic floor exercise)

Types of toileting (delayed voiding); bladder retraining (pelvic floor exercise, urge suppression, bladder diaries)

Types of toileting (delayed voiding); bladder retraining (pelvic floor exercise, urge suppression, bladder diaries)

(absolute risk difference $=-0.26 ; 95 \% \mathrm{CI},-0.40$ to -0.11) (Supplemental Figure 4, https://www.AnnFam Med.org/content/19/2/157/suppl/DC1/).

\section{Combined Self-Management and Drug Therapy vs Drug Therapy Alone}

Two of the studies we identified compared combined self-management and drug therapy vs drug therapy alone. $^{30,31}$ One of these studies, including 133 participants, found that the combination significantly reduced symptom severity on the IPSS compared with drug therapy alone at 6 weeks (MD $-2.30 ; 95 \% \mathrm{CI}_{1}-4.11$ to -0.49 ) (Figure $3 \mathrm{C}$ ). ${ }^{30}$

In terms of secondary outcomes, men in the combined intervention group reported fewer episodes of nocturia $(\mathrm{MD}=-0.45 ; 95 \% \mathrm{CI}-0.77$ to $-0.14 ; 2$ studies $^{30,31} ; \mathrm{I}^{2}=0 \%$; Supplemental Figure 2C, available at https://www.AnnFamMed.org/content/19/2/157/suppl/ $\mathrm{DC} 1 /)$ and voiding in 24 hours $(\mathrm{MD}=-2.10 ; 95 \% \mathrm{CI}$, -2.95 to $-1.25 ; 1$ study $^{30}$; Supplemental Figure 1C, https://www.AnnFamMed.org/content/19/2/157/suppl/ DC1/) compared with peers given drug therapy alone at 6 to 12 weeks.

Both studies reported data on adverse events at 6 to 12 weeks. No significant differences were observed in the frequency of adverse events between groups. ${ }^{30,31}$ For example, one study reported 1 serious adverse event in 65 participants $(1.54 \%)$ in the combination group compared with 2 in 68 participants $(2.94 \%)$ in the drug therapy group. ${ }^{30}$ 


\section{Single Components of Self-Management}

We identified 2 studies comparing single components of self-management for treating lower urinary tract symptoms. ${ }^{28,32}$ One study in men with postmicturition dribble compared pelvic floor muscle exercises, urethral milking, and counseling. ${ }^{32}$ This study found that pelvic floor exercise was most effective at reducing urine loss (4.7-g reduction in urine loss measured by weighing the moisture change in bodyworn pads at 13 weeks) compared with urethral milking (2.9-g reduction in urine loss). There was no improvement in urine loss in the counseling group. The other study, which was small, found no difference in symptom severity among men randomized to increased water consumption compared with peers randomized to placebo $(\mathrm{MD}=0.5 ; 95 \% \mathrm{CI}$, -0.9 to 2.0$).{ }^{28}$

\section{DISCUSSION}

Our review found moderate-quality evidence (suggesting reasonable certainty in estimates) for the effectiveness of self-management interventions for treating lower urinary tract symptoms in men. The 2 RCTs comparing self-management against usual care found a clinically meaningful 7.4-point reduction in symptom severity at 6 months. ${ }^{23,26,34}$ These reductions appear similar to those achieved with drug therapy. ${ }^{27,29}$ There was also a small but significant additional benefit of adding selfmanagement to drug therapy. ${ }^{30,31}$

The self-management interventions evaluated by the included studies used varying numbers and combinations of components. The way in which they were delivered to participants also varied (eg, delivered in groups vs individually, and at multiple time points vs once). Although the optimal package of the components of selfmanagement is not clear, it may not be necessary to include all components to achieve an effect that is important to patients. ${ }^{21}$ Individualized interventions focused on relieving a patient's most bothersome symptom might have a greater impact on their quality of life than those focused on total symptom severity scores. ${ }^{37}$

Our review had some limitations. First, variations and incomplete reporting of interventions precluded
Figure 2. Risk of bias assessment in included studies, both in individual studies and domains (top) and in summary (bottom).
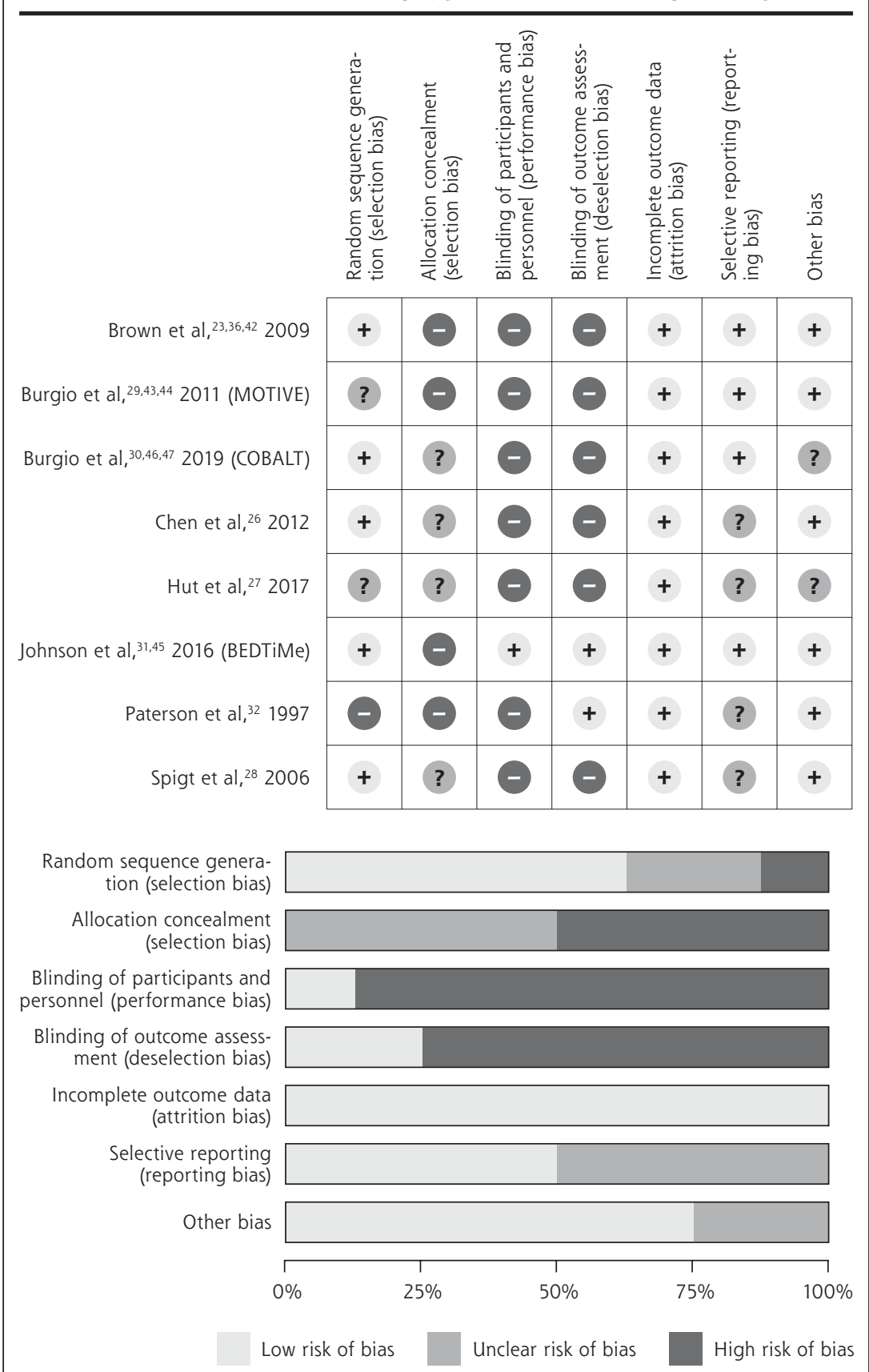

BEDTiMe = Behavior and Exercise Versus Drug Treatment in Men with Nocturia; COBALT = Combined Behavioral and Drug Treatment of Overactive Bladder in Men; MOTIVE = Male Overactive Bladder Treatment in Veterans. 
synthesis of the impact of individual components. This shortcoming is similar, however, to the inadequate reporting of nondrug interventions in general. ${ }^{38}$
Second, although the IPSS and AUA-SI scores are the most widely used symptom scores that can identify whether storage symptoms or voiding symptoms are

\begin{tabular}{|c|c|c|c|c|c|c|c|c|c|c|}
\hline \multirow{3}{*}{$\begin{array}{l}\begin{array}{l}\text { Study or } \\
\text { Subgroup }\end{array} \\
\begin{array}{c}\text { Brown et al, }{ }^{36} \\
2009\end{array}\end{array}$} & \multicolumn{2}{|c|}{$\begin{array}{c}\text { Self- } \\
\text { Management }\end{array}$} & \multicolumn{2}{|c|}{ Usual Care } & \multirow[b]{2}{*}{$\begin{array}{l}\text { Weight, } \\
\%\end{array}$} & \multirow{2}{*}{$\begin{array}{c}\text { Mean } \\
\text { Difference } \\
(95 \% \mathrm{Cl})\end{array}$} & \multirow{2}{*}{\multicolumn{3}{|c|}{ Mean Difference $(95 \% \mathrm{Cl})$}} & \\
\hline & \multirow{2}{*}{$\begin{array}{c}\begin{array}{c}\text { Mean } \\
\text { (SD) }\end{array} \\
10.4 \\
(6.1)\end{array}$} & \multirow{2}{*}{$\begin{array}{c}\begin{array}{c}\text { Total } \\
\text { No. }\end{array} \\
67\end{array}$} & \multirow{2}{*}{$\begin{array}{c}\begin{array}{c}\text { Mean } \\
\text { (SD) }\end{array} \\
16.9 \\
(6.4)\end{array}$} & \multirow{2}{*}{$\begin{array}{c}\begin{array}{c}\text { Total } \\
\text { No. }\end{array} \\
61\end{array}$} & & & & & & \\
\hline & & & & & 36.1 & $\begin{array}{c}-6.50 \\
(-8.67 \text { to }-4.33)\end{array}$ & & & & \\
\hline $\begin{array}{l}\text { Chen et al, }{ }^{26} \\
2012\end{array}$ & $\begin{array}{l}11.97 \\
(5.26)\end{array}$ & 119 & $\begin{array}{l}19.94 \\
(6.36)\end{array}$ & 103 & 63.9 & $\begin{array}{c}-7.97 \\
(-9.52 \text { to }-6.42)\end{array}$ & & & & \\
\hline \multirow[t]{3}{*}{ Overall } & & 186 & & 164 & 100.0 & $\begin{array}{c}-7.44 \\
(-8.82 \text { to }-6.06)\end{array}$ & & & T & \\
\hline & & & & & & & -10 & 0 & 5 & 10 \\
\hline & & & & & & & & & $\begin{array}{c}\text { Favors } \\
\text { usual care }\end{array}$ & \\
\hline
\end{tabular}

Figure 3B. Self-management intervention vs drug therapy, symptom severity at 6 to 12 weeks.

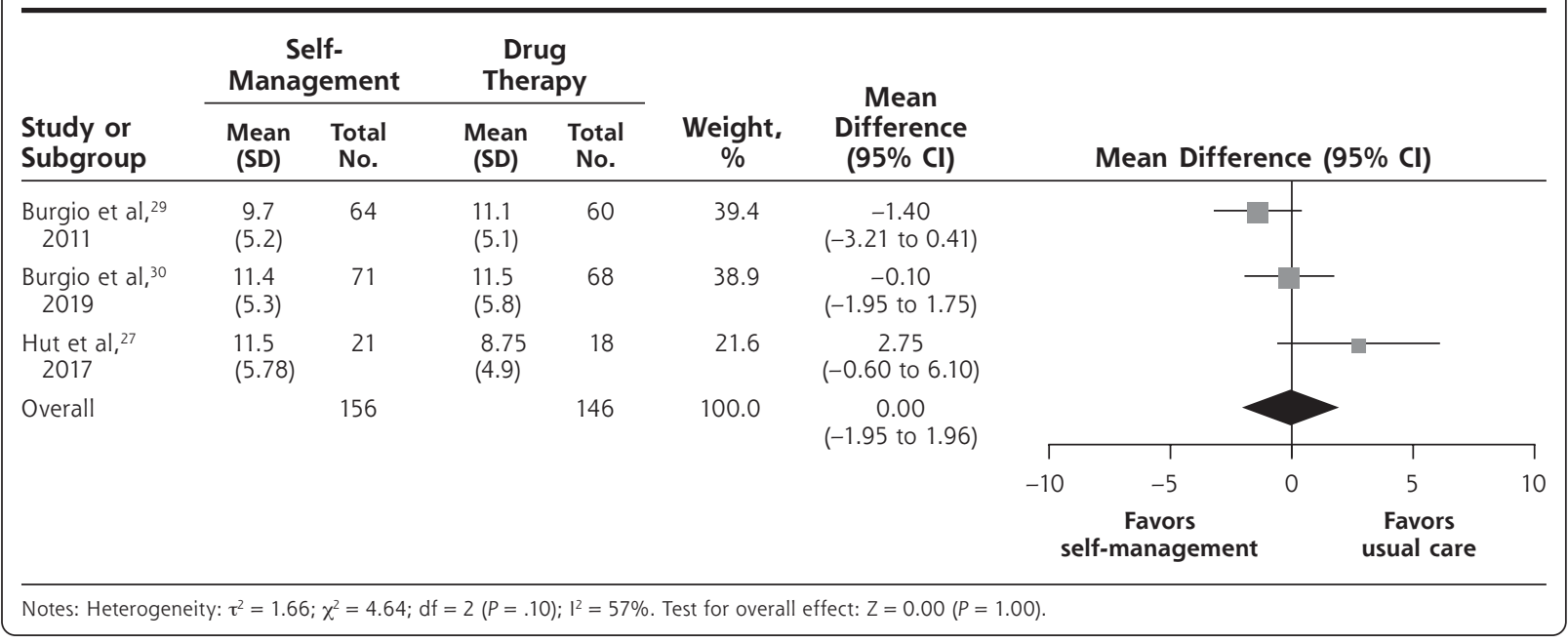

Figure 3C. Combined self-management intervention and drug therapy vs drug therapy alone, symptom severity at 6 weeks.

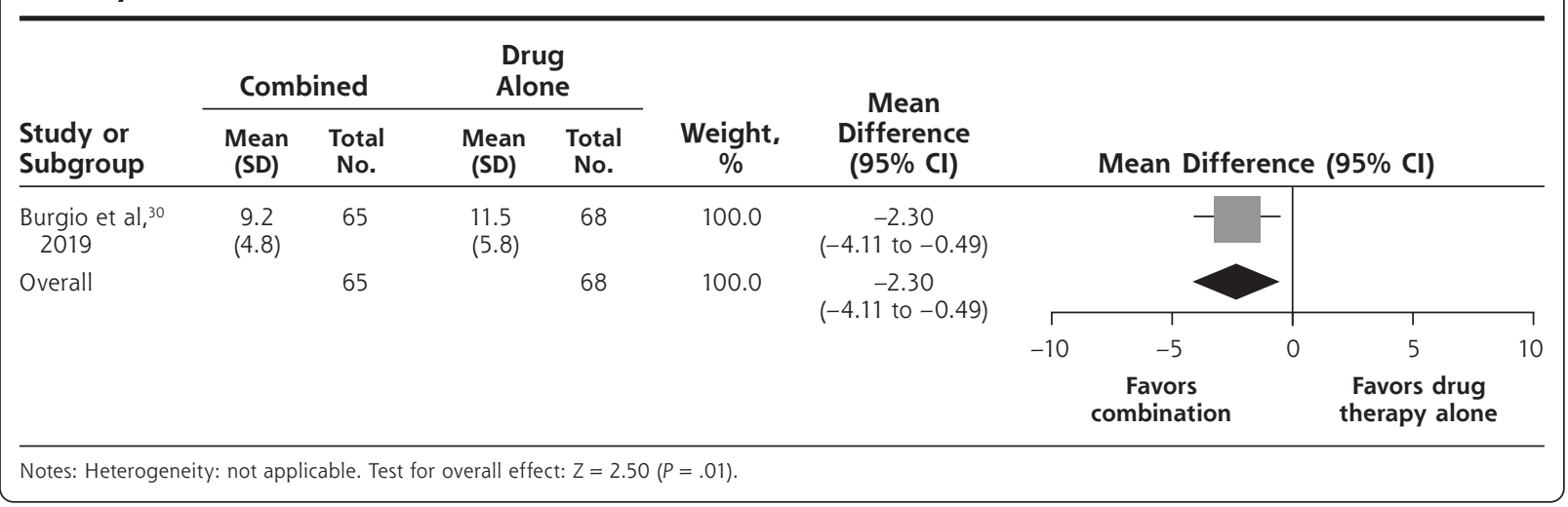


predominant, the lack of assessment of postmicturition dribble and incontinence as well as bother of symptoms is a considerable weakness. The International Consultation on Incontinence Questionnaire and the Danish Prostate Symptom Score are further well-established questionnaires that merit attention. ${ }^{39,40}$ Third, although symptom frequency is a relevant outcome for individuals, it is possible that a symptom can be frequent but not bothersome as individuals develop strategies to cope with that symptom. Finally, we did not have access to data at the level of individual patients; therefore, we could not investigate in which subgroups of patients (eg, patients with subsets of symptoms) which components of self-management had the largest effect. Strengths of our review include the thorough search supplemented by a check of all clinical trials registries and a forward and backward citation search for additional studies; duplicate assessment of eligibility, risk of bias, and data extraction; and verification of data accuracy with the authors of original studies.

Previous systematic reviews have shown that some nonpharmacologic interventions (eg, physical activity and weight loss not specifically designed to improve lower urinary tract symptoms) have no or limited effect, whereas others (eg, bladder training) might be beneficial in managing specific urinary symptoms (eg, incontinence) in men and women. A recent Cochrane review of 6 RCTs evaluating the effect of physical activity (eg, tai chi or intense exercise) for lower urinary tract symptoms found a very low quality of evidence supporting the use of physical activity. ${ }^{17}$ Another Cochrane review of 10 RCTs of bladder training in adults, conducted in 2014, suggested that bladder training may be helpful in treating urinary incontinence, but the majority of the participants in included trials were women (1,350 of 1,473 participants). ${ }^{41}$ A separate 2015 Cochrane review on lifestyle interventions for treating incontinence in adults examined a range of interventions and found evidence to be strongest for weight loss, but also determined that the 3 trials of reducing caffeinated drinks did not show any impact. ${ }^{18}$

Further research on self-management of lower urinary tract symptoms in men is warranted to identify optimal components and delivery methods, and studies should continue to follow participants for longer durations (12 months or more). Online delivery of a self-management intervention that can be tailored to personal characteristics and symptom severity is being tested. ${ }^{21}$ These residual uncertainties, however, should not prevent routine use of self-management in clinical practice as a standard option for men with lower urinary tract symptoms. Implementation would be enhanced by obtaining professional consensus on the self-management package, promoting this package through primary care and urologic professional groups, and including patient information sheets and decision aids.

To read or post commentaries in response to this article, go to https://www.AnnFamMed.org/content/19/2/157/tab-e-letters.

Key words: self-management; lower urinary tract symptoms; urinary incontinence; nocturia; overactive bladder; benign prostatic hyperplasia; non-pharmacological intervention

Submitted February 3, 2020; submitted, revised, June 11, 2020; accepted June 17, 2020.

Author contributions: L.A., S.S., P.G. designed the study. L.A., S.S. screened articles. L.A., S.S. extracted data. L.A. drafted the original manuscript; all authors revised the paper. The corresponding author attests that all listed authors meet authorship criteria and that no others meeting the criteria have been omitted. L.A. is the guarantor of the study.

Protocol registration: Open Science Framework: https://osf.io/whkqz.

Acknowledgments: We thank lain Chalmers and Les Irwig for providing helpful comments and feedback on earlier version of this manuscript.

Data sharing: Data extracted from the included studies are available on request from the corresponding author.

Supplemental materials: Available at https://www.AnnFamMed. org/content/19/2/157/suppl/DC1/.

\section{References}

1. Hollingsworth JM, Wilt TJ. Lower urinary tract symptoms in men. BMJ. 2014;349:g4474.

2. Parsons JK, Bergstrom J, Silberstein J, Barrett-Connor E. Prevalence and characteristics of lower urinary tract symptoms in men aged $>$ or $=80$ years. Urology. 2008;72(2):318-321.

3. D'Silva KA, Dahm P, Wong CL. Does this man with lower urinary tract symptoms have bladder outlet obstruction? The Rational Clinical Examination: a systematic review. JAMA. 2014;312(5):535-542.

4. D'Ancona C, Haylen B, Oelke M, et al; Standardisation Steering Committee ICS and the ICS Working Group on Terminology for Male Lower Urinary Tract \& Pelvic Floor Symptoms and Dysfunction. The International Continence Society (ICS) report on the terminology for adult male lower urinary tract and pelvic floor symptoms and dysfunction. Neurourol Urodyn. 2019;38(2):433-477.

5. Thorpe A, Neal D. Benign prostatic hyperplasia. Lancet. 2003; 361(9366):1359-1367.

6. Gratzke C, Bachmann A, Descazeaud A, et al. EAU guidelines on the assessment of non-neurogenic male lower urinary tract symptoms including benign prostatic obstruction. Eur Urol. 2015;67(6): 1099-1109.

7. Chapple $(R$, Wein $A J$, Abrams $P$, et al. Lower urinary tract symptoms revisited: a broader clinical perspective. Eur Urol. 2008;54(3): 563-569.

8. The National Institute for Health and Care Excellence (NICE). Clinical guideline CG97: Lower urinary tract symptoms in men: management. https://www.nice.org.uk/guidance/cg97. Published 2010. Accessed Nov 9, 2019.

9. Agarwal A, Eryuzlu LN, Cartwright R, et al. What is the most bothersome lower urinary tract symptom? Individual- and populationlevel perspectives for both men and women. Eur Urol. 2014;65(6): 1211-1217.

10. Coyne KS, Sexton CC, Irwin DE, Kopp ZS, Kelleher CJ, Milsom I. The impact of overactive bladder, incontinence and other lower urinary tract symptoms on quality of life, work productivity, sexuality and emotional well-being in men and women: results from the EPIC study. BJU Int. 2008;101(11):1388-1395. 
11. Taylor BC, Wilt TJ, Fink HA, et al; Osteoporotic Fractures in Men (MrOS) Study Research Group. Prevalence, severity, and health correlates of lower urinary tract symptoms among older men: the MrOS study. Urology. 2006;68(4):804-809.

12. Helfand BT, McVary KT, Meleth S, et al.; CAMUS Study Group. The relationship between lower urinary tract symptom severity and sleep disturbance in the CAMUS trial. J Urol. 2011;185(6):2223-2228.

13. Grady PA, Gough LL. Self-management: a comprehensive approach to management of chronic conditions. Am J Public Health. 2014; 104(8):e25-e31.

14. Narasimhan M, Allotey $P$, Hardon A. Self care interventions to advance health and wellbeing: a conceptual framework to inform normative guidance. BMJ. 2019;365:1688.

15. Greaves CJ, Campbell JL. Supporting self-care in general practice. $\mathrm{Br}$ J Gen Pract. 2007;57(543):814-821.

16. Brown CT, van der Meulen J, Mundy AR, O'Flynn E, Emberton M. Defining the components of a self-management programme for men with uncomplicated lower urinary tract symptoms: a consensus approach. Eur Urol. 2004;46(2):254-262, discussion 263.

17. Silva V, Grande AJ, Peccin MS. Physical activity for lower urinary tract symptoms secondary to benign prostatic obstruction. Cochrane Database Syst Rev. 2019;4(4):CD012044.

18. Imamura M, Williams K, Wells M, McGrother C. Lifestyle interventions for the treatment of urinary incontinence in adults. Cochrane Database Syst Rev. 2015;(12):CD003505.

19. Rai BP, Cody JD, Alhasso A, Stewart L. Anticholinergic drugs versus non-drug active therapies for non-neurogenic overactive bladder syndrome in adults. Cochrane Database Syst Rev. 2012;12(12): CD003193.

20. Roe B, Williams K, Palmer M. Bladder training for urinary incontinence in adults. Cochrane Database Syst Rev. 2000;(2):CD001308.

21. Blanker MH, Brandenbarg P, Slijkhuis BGC, Steffens MG, van Balken $M R$, Jellema P. Development of an online personalized self-management intervention for men with uncomplicated LUTS. Neurourol Urodyn. 2019;38(6):1685-1691.

22. Liberati A, Altman DG, Tetzlaff J, et al. The PRISMA statement for reporting systematic reviews and meta-analyses of studies that evaluate healthcare interventions: explanation and elaboration. BMJ. 2009;339:b2700.

23. Brown CT, Yap T, Cromwell DA, et al. Self management for men with lower urinary tract symptoms: randomised controlled trial. BMJ. 2007;334(7583):25.

24. Higgins JP, Altman DG, Gøtzsche PC, et al; Cochrane Bias Methods Group; Cochrane Statistical Methods Group. The Cochrane Collaboration's tool for assessing risk of bias in randomised trials. BMJ. 2011;343:d5928.

25. Higgins JPT, Green S, eds. Cochrane Handbook for Systematic Reviews of Interventions Version 5.1.0. United Kingdom: The Cochrane Collaboration; 2011.

26. Chen $Y$, Zhang $X, H u X$, et al. The potential role of a self-management intervention for benign prostate hyperplasia. Urology. 2012; 79(6):1385-1388.

27. Hut J, van der Heide W/K, Kollen BJ, Messelink EJ, Blanker MH, Dekker JH. Pelvic floor muscle therapy or alpha-blocking agents for treatment of men with lower urinary tract symptoms: an exploratory randomized controlled trial. Int J Urol. 2017;24(6):473-474.

28. Spigt $M$, van Schayck $O$, Knipschild $P$, et al. Is it possible to improve elderly male bladder function by having them drink more water? A randomized trial of effects of increased fluid intake/urine output on male lower urinary tract function. Urology. 2006;68(5):1031-1036.

29. Burgio KL, Goode PS, Johnson TM, et al. Behavioral versus drug treatment for overactive bladder in men: the Male Overactive Bladder Treatment in Veterans (MOTIVE) Trial. J Am Geriatr Soc. 2011; 59(12):2209-2216.
30. Burgio KL, Kraus SR, Johnson TM II, et al. Effectiveness of combined behavioral and drug therapy for overactive bladder symptoms in men: a randomized clinical trial. JAMA Intern Med. 2020;180(3):411-419.

31. Johnson TM II, Vaughan CP, Goode PS, et al. Pilot results from a randomized trial in men comparing alpha-adrenergic antagonist versus behavior and exercise for nocturia and sleep. Clin Ther. 2016; S0149-2918(16)30742-1.

32. Paterson J, Pinnock CB, Marshall VR. Pelvic floor exercises as a treatment for post-micturition dribble. Br J Urol. 1997;79(6):892-897.

33. Azizi M, Azadi A, Otaghi M. The effect of a self-care programme on urinary incontinence and self-esteem in elderly men dwelling in nursing homes in Iran. Aging Male. 2019;1-7.

34. Barry MJ, Williford WO, Chang Y, et al. Benign prostatic hyperplasia specific health status measures in clinical research: how much change in the American Urological Association symptom index and the benign prostatic hyperplasia impact index is perceptible to patients? J Urol. 1995;154(5):1770-1774.

35. Blanker MH, Alma HJ, Devji TS, Roelofs M, Steffens MG, van der Worp H. Determining the minimal important differences in the International Prostate Symptom Score and Overactive Bladder Questionnaire: results from an observational cohort study in Dutch primary care. BMJ Open. 2019;9(12):e032795.

36. Yap TL, Brown C, Cromwell DA, van der Meulen J, Emberton M. The impact of self-management of lower urinary tract symptoms on frequency-volume chart measures. BJU Int. 2009;104(8):1104-1108.

37. Lee SW, Doo SW, Yang WJ, Song YS. Importance of relieving the most bothersome symptom for improving quality of life in male patients with lower urinary tract symptoms. Urology. 2012;80(3): 684-687.

38. Hoffmann TC, Erueti C, Glasziou PP. Poor description of nonpharmacological interventions: analysis of consecutive sample of randomised trials. BMJ. 2013;347:f3755.

39. Hansen BJ, Flyger $H$, Brasso $K$, et al. Validation of the self-administered Danish Prostatic Symptom Score (DAN-PSS-1) system for use in benign prostatic hyperplasia. Br J Urol. 1995;76(4):451-458.

40. Donovan JL, Peters TJ, Abrams P, Brookes ST, de aa Rosette JJ, Schäfer W. Scoring the short form ICSmaleSF questionnaire. International Continence Society. J Urol. 2000;164(6):1948-1955.

41. Wallace SA, Roe B, Williams K, Palmer M. Bladder training for urinary incontinence in adults. Cochrane Database Syst Rev. 2004(1): CD001308.

42. Brown CT, Emberton M. Self-management for men with lower urinary tract symptoms. Curr Urol Rep. 2009;10(4):261-266.

43. Burgio K, Goode P, Johnson T, Ouslander J, Hammontree L, Redden D. Behavioral versus drug treatment for overactive bladder in men: a randomized controlled trial. Abstract 552. Proceedings of the 39th Annual Meeting of the International Continence Society (ICS); Sep 29-Oct 3, 2009; San Francisco, CA.

44. Burgio KL, Goode PS, Johnson TM, et al. Behavioral vs. drug treatment for overactive bladder in men: the MOTIVE trial. J Urol. 2010; 183(4):e585.

45. Johnson J, Vaughan C, Goode P, et al. Efficacy of multicomponent behavioral treatment, alpha-adrenergic antagonist, and combined therapy in men with nocturia: the BEDTiMe trial. Abstract PD23-10. J Urol. 2014;191(4)(Suppl 1):e670.

46. Burgio K, Kraus S, Johnson TM, et al. Combined behavioral and drug treatment of lower urinary tract symptoms in men: the COBALT randomized trial. J Urol. 2018;199(S4):e1139.

47. Burgio K, Kraus S, Johnson NT, et al. Conservative management award (joint) sponsored by Essity. Combined behavioral and drug treatment of lower urinary tract symptoms in men: the COBALT randomized controlled trial. Neurourol Urodyn. 2018;37(S5):S318. 